\title{
Mineral nutrition and fertilization of sweet potato
}

\author{
Nutrição mineral e adubação da batata-doce
}

\author{
Adalton Mazetti FERNANDES ${ }^{1}$; Nathalia Pereira RIBEIRO²
}

${ }^{1}$ Autor para correspondência Pesquisador IV, Universidade Estadual Paulista (UNESP), Centro de Raízes e Amidos Tropicais (CERAT), Fazenda Experimental Lageado, Botucatu, SP, Brasil. e-mail: adalton.fernandes@unesp.br.

${ }^{2}$ Doutora em Agronomia (Horticultura), Universidade Estadual Paulista (UNESP), Faculdade de Ciências Agronômicas (FCA), Fazenda Experimental Lageado, Botucatu, SP, Brasil. e-mail: nathaliaribeiropr@gmail.com

Recebido em: 03-09-2020; Aceito em: 10-11-2020

\begin{abstract}
Sweet potato (Ipomoea batatas L.) is a versatile crop, but it is often grown in marginal and low-fertility areas, which reflects storage root yields far below its potential. For this reason, balanced liming and fertilization in sweet potato are essential to increase crop yield. Based on this approach, themes related to the nutritional requirements of sweet potato are presented and discussed considering the main cultivars currently used in Brazil as well as references for rational fertilization management in this crop. Sweet potato is a crop that absorbs large amounts of nutrients during its development cycle, but this should not be used as a prerogative to excessively increase the fertilizer rates applied in this root crop. As a strategy for rational fertilization management, one should take advantage of the ability of this crop to associate with $\mathrm{N}$-fixing microorganisms, thus reducing the use of mineral $\mathrm{N}$. Moreover, it is necessary to encourage the use of organic fertilizer, whether using animal manure or green manure. In addition to increasing storage root yield and improving storage root shape, organic fertilizers can partially replace mineral chemical fertilizers. Studies aimed at updating cultivar-specific potassium and phosphate fertilizer recommendations should also be encouraged, as well as research addressing micronutrient supply for sweet potato.
\end{abstract}

Additional keywords: Ipomoea batatas L.; mineral fertilizer; nutrients; nutritional status; organic fertilizer.

\section{Resumo}

A batata-doce (Ipomoea batatas L.) é uma cultura versátil, mas muitas vezes ela é cultivada em áreas marginais e de baixa fertilidade, o que reflete em produtividade de raízes tuberosas muito abaixo do potencial dessa cultura. Por isso, as práticas de calagem e adubação balanceadas na batata-doce são essenciais para se aumentar a produtividade dessa cultura. Com base nesta abordagem, são apresentados e discutidos temas relacionados às exigências nutricionais da batata-doce, baseando-se nas principais cultivares utilizadas atualmente no Brasil, bem como referências para um manejo racional da adubação na cultura da batata-doce. Neste contexto, é possível observar que a batata-doce é uma cultura que absorve grandes quantidades de nutrientes durante seu ciclo de desenvolvimento, mas isto não deve ser usado como prerrogativa para se aumentar exageradamente as doses de fertilizantes aplicadas nesta cultura. Como uma estratégia para o manejo racional da adubação na batata-doce, deve-se tirar proveito da capacidade que essa planta tem de se associar com microrganismos fixadores de $\mathrm{N} \mathrm{e}$ reduzir o uso de $\mathrm{N}$ mineral. Além disso, é preciso estimular o emprego de adubação orgânica, seja utilizando resíduos animais ou adubos verdes, pois além de aumentar a produtividade de raízes tuberosas e melhorar o formato delas, a adubação orgânica também pode substituir, em parte, a adubação química mineral. Trabalhos para atualização das recomendações de adubação potássica e fosfatada específicas por cultivar também devem ser estimulados, além de pesquisas envolvendo o suprimento de micronutrientes para a batata-doce.

Palavras-chave adicionais: adubação mineral; adubação orgânica; estado nutricional; Ipomoea batatas L.; nutrientes.

\section{Introduction}

Sweet potato (Ipomoea batatas L.) can be used in human and animal food and in the industrial sector. The sweet potato plant has two types of roots: fibrous roots and storage roots. Fibrous roots absorb water and nutrients from the soil, reaching up to $0.90 \mathrm{~m}$ in depth (Filgueira, 2008). This well-developed root system provides rusticity to the sweet potato plant. Storage roots, on the other hand, are the part of commercial interest. These roots are characterized by greater thickness and little presence of secondary roots, and originate from nodes present in the below-ground stem (Silva et al., 2002; Echer et al., 2009a).

In Brazil, sweet potato planting usually occurs in areas of infertile and sandy soils or in pasture restoration areas (Echer et al., 2015). The sweet potato crop does not have a high response to fertilizer application, and shows good yield in marginal soils (Silva et al., 2002; Filgueira, 2008). However, adequate nutrient supply is indispensable for sweet potato to obtain high storage root yield because, in high-yield crops, this plant 
absorbs large amounts of nutrients from the soil (Echer et al., 2009a).

Assessing the nutritional status of sweet potato through leaf tissue collection, analysis, and comparison with the sufficiency ranges of the official recommendation bulletins is still the most accurate way to analyze whether the nutrient supply for the crop is adequate or not. This assessment, together with the soil analysis, allows to adapt the fertilization management so that the crop can express its full yield potential (Faquin, 2002). Thus, knowing which nutrient the sweet potato plant needs most, as well as the quantity and the appropriate timing of its supply, are fundamental for the nutritional balance of the plant since the nutrients must be applied according to crop requirements.

This brief review aims to disseminate knowledge about the nutritional requirements and the nutritional status of sweet potato, as well as to provide the basis for rational fertilization in the cultivation of sweet potato under Brazilian growing conditions.

\section{Absorption dynamics, amounts absorbed and removed by the sweet potato crop}

Knowing the amounts of nutrients absorbed and removed by sweet potato is important for proper fertilization management in this crop. The nutrient demand of sweet potato is relatively high (Echer et al., 2009a), as are the quantities of nutrients removed, especially if yield is high and shoots and storage roots are removed from the field (Lebot, 2009).

Potassium (K) and nitrogen $(\mathrm{N})$ are the nutrients most absorbed by sweet potato, with values ranging between 225 and $376 \mathrm{~kg} \mathrm{ha}^{-1} \mathrm{~K}$ and between 215 and $350 \mathrm{~kg} \mathrm{ha}^{-1} \mathrm{~N}$, respectively (O'Sullivan et al., 1997; Echer et al., 2009a). However, nutrient absorption by sweet potato plants up to 50 days after planting (DAP) is low (Echer et al., 2009a) (Figure 1) because storage roots are not yet present at this stage. After $50 \mathrm{DAP}$, the development of storage roots (reserve accumulation) intensifies and there is a strong increase in the absorption of nutrients until near the end of the crop cycle, which occurs at approximately 145 DAP (Echer et al., 2009a) (Figure 1). Up to 85 DAP, sweet potato absorbs approximately $50 \%$ of its total $\mathrm{Mg}, \mathrm{S}$, and $\mathrm{Mn}$ needs, and about $80 \%$ of all the total Fe needed (Figure 1). Between 85 DAP and the end of the cycle (a period of about 60 days), sweet potato plants absorb between $68 \%$ and $74 \%$ of their needs in $\mathrm{N}, \mathrm{P}, \mathrm{K}, \mathrm{Ca}$, and $\mathrm{B}$, and approximately $77 \%$ to $79 \%$ of the total $\mathrm{Cu}$ and $\mathrm{Zn}$ needed.

In general, the amounts of nutrients absorbed and removed per hectare by the sweet potato crop vary according to several factors. However, the amounts of nutrients absorbed and removed per ton of storage root produced show less variation, even when yield levels are quite different (Rós et al., 2015). Some studies indicate that to produce a ton of storage root, sweet potato plants absorbs, on average, 6.9, 5.1, 2.5, 0.8, 0.7, and $0.6 \mathrm{~kg}$ of $\mathrm{K}, \mathrm{N}, \mathrm{Ca}, \mathrm{P}, \mathrm{Mg}$, and $\mathrm{S}$, respectively (Figure 2a).
Few studies have evaluated the demand of sweet potato for micronutrients in tropical growing conditions (Echer et al., 2009a; Fernandes et al., 2020). Nonetheless, some studies indicate that the amounts of micronutrients absorbed by sweet potato to produce one ton of storage root are approximately $16.2 \mathrm{~g}$ of $\mathrm{Mn}$, $10.6 \mathrm{~g}$ of $\mathrm{Fe}, 7.5 \mathrm{~g}$ of $\mathrm{B}, 5.6 \mathrm{~g}$ of $\mathrm{Zn}, 3.4 \mathrm{~g}$ of $\mathrm{Cu}$, and $0.5 \mathrm{~g}$ of Mo (Figure $2 \mathrm{~b}$ ).

The removal of nutrients from the field for each ton of storage root is approximately $4.1 \mathrm{~kg}$ of $\mathrm{K}, 2.6 \mathrm{~kg}$ of $\mathrm{N}, 0.5 \mathrm{~kg}$ of $\mathrm{P}, 0.4 \mathrm{~kg}$ of $\mathrm{Ca}, 0.3 \mathrm{~kg}$ of $\mathrm{Mg}, 0.2 \mathrm{~kg}$ of $\mathrm{S}$, $3.9 \mathrm{~g}$ of Fe, $2.7 \mathrm{~g}$ of $\mathrm{Zn}, 2.6 \mathrm{~g}$ of $\mathrm{Mn}, 2.1 \mathrm{~g}$ of $\mathrm{B}, 1.5 \mathrm{~g}$ of $\mathrm{Cu}$, and $0.3 \mathrm{~g}$ de Mo (Figures $2 \mathrm{a}, 2 \mathrm{~b}$ ). Thus, of the total nutrients absorbed by sweet potato plants during their development cycle, more than $50 \%$ of the total amounts of $\mathrm{N}, \mathrm{P}, \mathrm{K}$, and Mo absorbed are removed by the storage roots; however, for the nutrients $\mathrm{Mg}, \mathrm{S}, \mathrm{Cu}, \mathrm{Fe}$, and $\mathrm{Zn}$, these values are between $37 \%$ and $49 \%$ (Figure 2c). Only $28 \%$ of the total B absorbed by sweet potato plants is removed by the storage roots, and most of the $\mathrm{Ca}$ and $\mathrm{Mn}$ absorbed by the plants is retained in the shoots, with less than $17 \%$ of the total absorbed during the crop cycle being removed from the field with the harvest of storage roots. Thus, at least $40 \%$ of the nutrients absorbed by plants during the development cycle remain in the shoots (Figure $2 \mathrm{c}$ ) and can return to the soil along with plant residues. Notwithstanding, when shoots are also harvested, a greater monitoring of soil fertility should be carried out because the nutrients removal from the field increases by at least $40 \%$.

\section{Diagnosis of nutritional status}

For sweet potato plants to develop properly, with high yield, they need nutrients to be provided in a balanced way (Rós et al., 2015).

Chemical analysis of leaves is still the most suitable method to assess the nutritional status of sweet potato; however, the sampling methodology varies. Lorenzi et al. (1997) recommend collecting new fully developed leaves at 60 DAP, while O'Sullivan et al. (1997) suggest collecting the seventh to ninth leaf blade, from the tip of the branches, at 28 DAP. Situations where leaf nutrient concentrations are below the adequate range (according to the methodology of each author) (Table 1) fertilizer supplementation is required to correct nutritional deficiency either during the current growing season or for subsequent growing seasons.

\section{Nutritional disorders}

Nutrient deficiency or excess causes visible changes in various organs of sweet potato plants, mainly in the leaves. However, considering the functions of nutrients in the plant, each nutritional disorder tends to produce characteristic symptoms (O'Sullivan et al., 1997). 

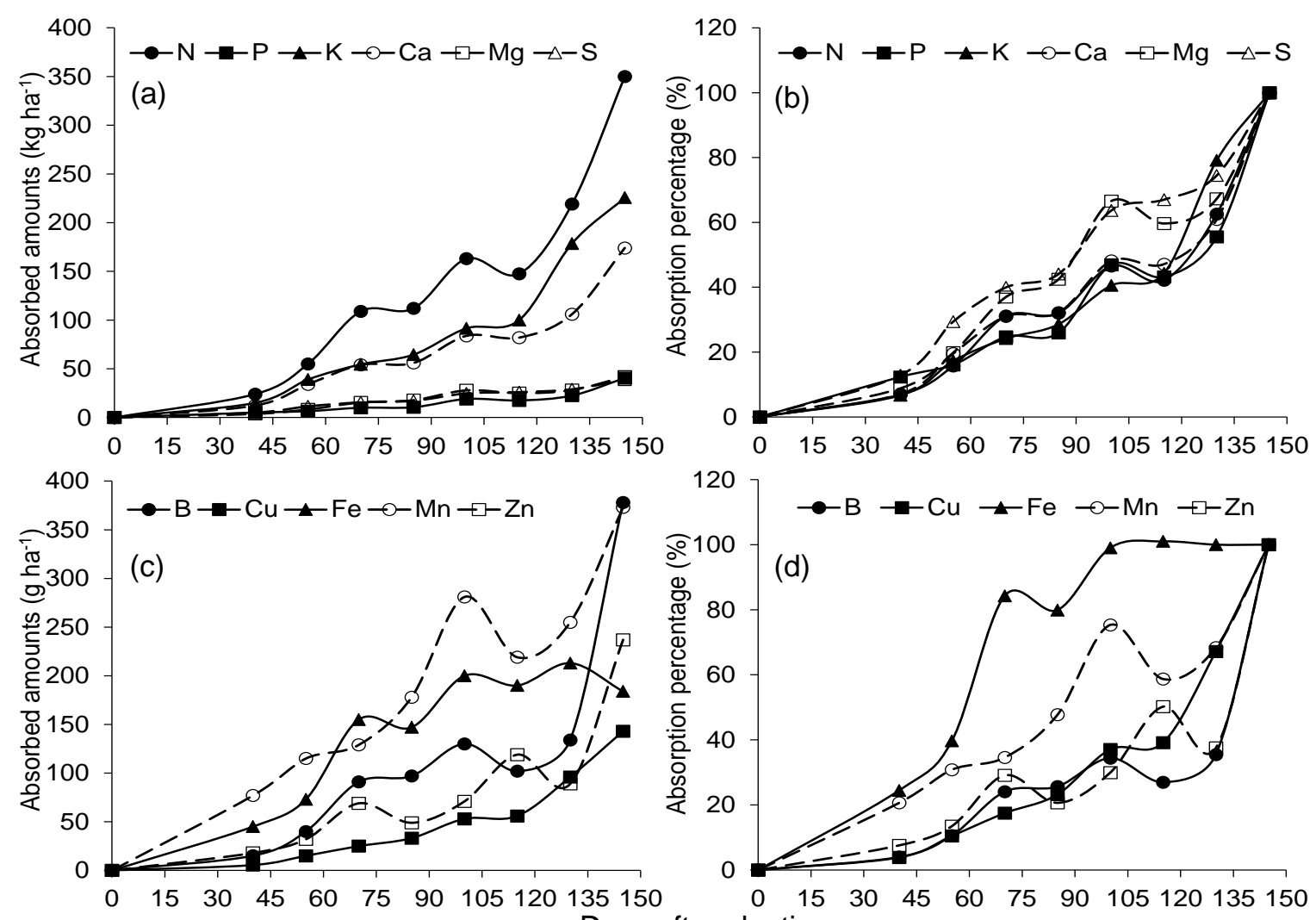

Days after planting

Figure 1 - Amounts of nutrients absorbed per hectare $(a, c)$ and percentage of nutrients absorbed $(b, d)$ throughout the development cycle of sweet potato plants 'Canadense'. Source: Adapted from Echer et al. (2009).
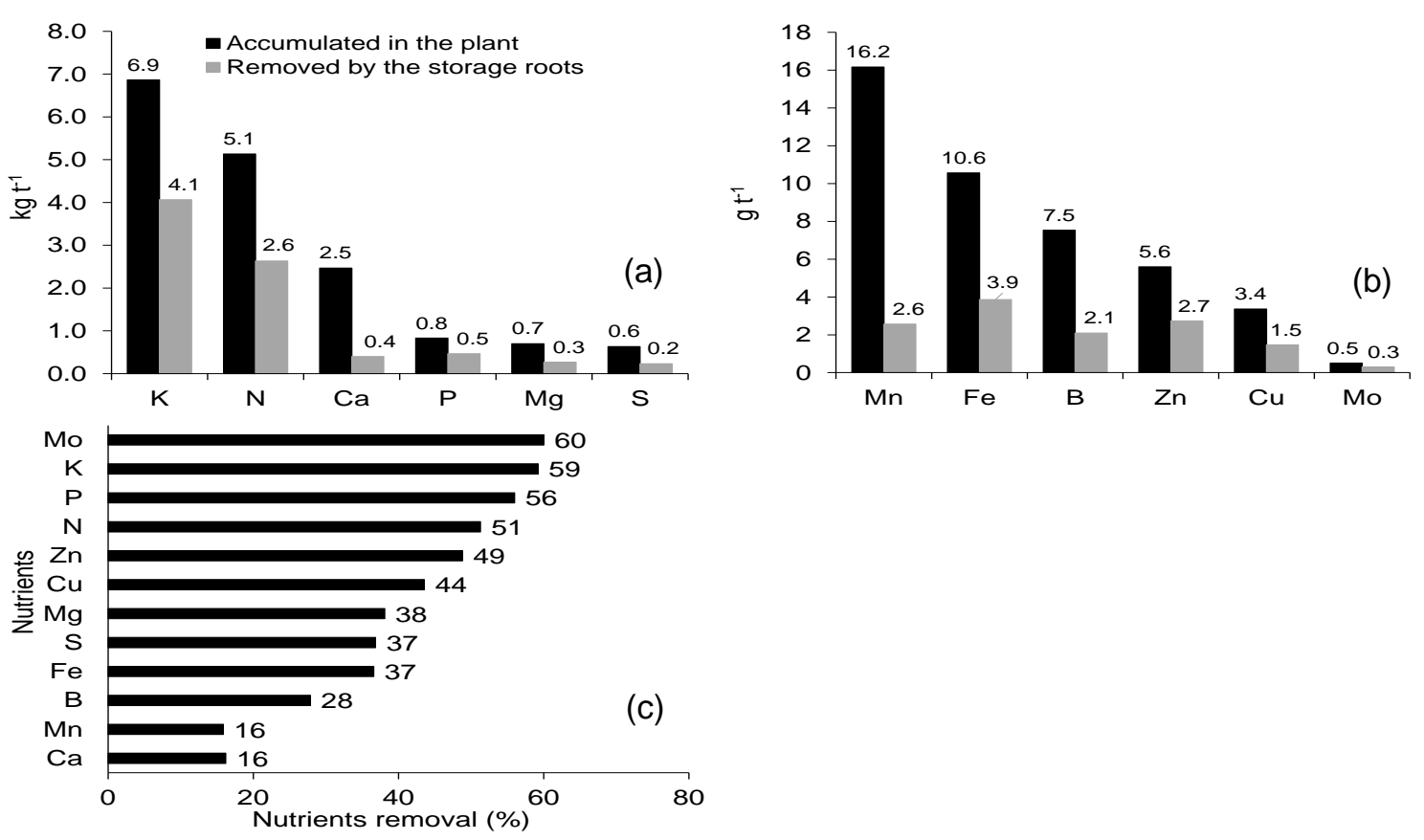

Figure 2 - Nutrient accumulation by the sweet potato plant, nutrient removal per ton of storage roots (a, b), and percentage of nutrients removed by the storage roots in relation to the total amounts accumulated by the plants. Source: Average values calculated using data from Miranda et al. (1995), O'Sullivan et al. (1997), and Echer et al. (2009). 
Table 1 - Range of leaf suitable concentration of macro $\left(\mathrm{g} \mathrm{kg}^{-1}\right)$ and micronutrient $\left(\mathrm{mg} \mathrm{kg}^{-1}\right)$ for sweet potato crop.

\begin{tabular}{lrrrrrrr}
\hline Nutrient & \multicolumn{2}{c}{ Lorenzi et al. (1997) } & \multicolumn{3}{c}{ O'Sullivan et al. (1997) } \\
\hline $\mathrm{N}$ & 33 & - & 45 & 42 & - & 50 \\
$\mathrm{P}$ & 2.3 & - & 5 & 2.6 & - & 4.5 \\
$\mathrm{~K}$ & 31 & - & 45 & 28 & - & 60 \\
$\mathrm{Ca}$ & 7 & - & 12 & 9 & - & 12 \\
$\mathrm{Mg}$ & 3 & - & 12 & 1.5 & - & 3.5 \\
$\mathrm{~S}$ & 4 & - & 7 & 3.5 & - & 4.5 \\
$\mathrm{~B}$ & 25 & - & 75 & 50 & - & 200 \\
$\mathrm{Cu}$ & 10 & - & 20 & 5 & - & 14 \\
$\mathrm{Fe}$ & 40 & - & 100 & 45 & - & 80 \\
$\mathrm{Mn}$ & 40 & - & 250 & 26 & - & 500 \\
$\mathrm{Mo}$ & - & - & - & 0.5 & - & 7 \\
$\mathrm{Zn}$ & 20 & - & 50 & 30 & - & 60 \\
\hline
\end{tabular}

The assessment of visual symptoms, despite being a simple and quick tool, has limitations. This is because similar symptoms can be caused by different nutrients, and multiple nutrient deficiencies can occur at the same time in the plant (Souza et al., 2015). In addition, the action of pests and pathogens can cause symptoms in plants, which makes it difficult to detect the problematic nutrient. Thus, chemical analysis of sweet potato leaves allows the diagnosis of nutritional disor- ders in plants (O'Sullivan et al., 1997), although this tool has still been little used in sweet potato cultivation areas in Brazil (Echer \& Creste, 2015). O'Sullivan et al. (1997) established critical levels of nutrient deficiency and toxicity in leaf blades of the sweet potato cultivar Wanmun in studies with nutrient solution (Table 2), but no research in this regard has been carried out with sweet potato cultivars planted in Brazil.

Table 2 - Critical deficiency and toxicity concentrations of macro $\left(\mathrm{g} \mathrm{kg}^{-1}\right)$ and micronutrient $\left(\mathrm{mg} \mathrm{kg}^{-1}\right)$ in the sweet potato, measured in the seventh to ninth leaf blades from shoot tip at 28 days after planting. Source: O'Sullivan et al. (1997).

\begin{tabular}{lcc}
\hline Nutrient & Deficiency & Toxicity \\
\hline $\mathrm{N}$ & 40 & - \\
$\mathrm{P}$ & 2.2 & - \\
$\mathrm{K}$ & 26 & - \\
$\mathrm{Ca}$ & 7.6 & - \\
$\mathrm{Mg}$ & 1.2 & - \\
$\mathrm{S}$ & 3.4 & $>220$ \\
$\mathrm{~B}$ & 40 & 15.5 \\
$\mathrm{Cu}$ & $<5.0$ & - \\
$\mathrm{Fe}$ & 33 & 1600 \\
$\mathrm{Mn}$ & 19 & - \\
$\mathrm{Mo}$ & 0.2 & $>70$ \\
$\mathrm{Zn}$ & 11 & \\
\hline
\end{tabular}

In this context, O'Sullivan et al. (1997) presented a detailed description of the symptoms of nutritional disorders in sweet potatoes. The following is a summary of the main symptoms of nutritional imbalance described by these authors:

$\mathbf{N}$ : Nitrogen deficiency drastically reduces sweet potato growth. Nitrogen-deficient plants show uniform chlorosis in the leaves and slow growth. There may be yellowing and premature fall of old leaves, which become uniformly yellow and slightly wilted. Plants with severe $\mathrm{N}$ deficiency present smaller leaves, with uniform pale color, which are dull with thin branches and less branching.

P: Phosphorus deficiency can halve plant growth without causing visual symptoms. Under P deficiency, young and mature leaves remain dark green, and old leaves show premature senescence. Yellowing of old leaves is preceded by the appearance of purple color (anthocyanins). Chlorotic areas may turn orange or red due to anthocyanin. Some young leaves of deficient plants may have purple veins.

K: Potassium-deficient plants produce small, thin, lowquality storage roots. The orange-fleshed sweet potato cultivars have a paler color than normal. Deficiency symptoms generally occur during the storage root bulking phase. Old leaves turn yellow, while new leaves retain their normal color, size, and texture. Old leaves develop chlorosis in the marginal and intermediate zones, evolving into necrotic and brown lesions that occupy the entire leaf blade. The necrotic areas caused by $\mathrm{K}$ deficiency are dark, dry, and brittle. 
Ca: Calcium deficiency inhibits root growth and causes death of root tips in severe cases. The main symptom of this deficiency is necrosis of young leaves, which begins at the lateral margins and extends to the center of the leaf blade. The necrotic tissue is dark brown and brittle. Necrosis is not preceded by localized chlorosis. The symptom occurs initially in young, expanding leaves, and culminates in the death of the stem apex.

Mg: Magnesium deficiency causes interveinal chlorosis in old leaves. Chlorosis appears initially in old leaves and can spread to young leaves, sometimes curving above or below leaf margins. Under chlorosis, old leaves can turn purple or reddish-brown. The branches of Mg-deficient plants are thin, intertwined, and have elongated internodes (similar to the branches etiolation symptom).

S: Severe sulfur deficiency reduces leaf size and the number of branches. In green leaf cultivars, new leaves become chlorotic before mature leaves, but in cultivars where the branch tip is red or purple, this symptom is not visible. Purple or reddish-brown pigmentation can also occur on new and old leaves of S-deficient plants.

B: Severe boron deficiency causes death of growth points, necrotizing the tip of branches and the axillary buds of the stem. In B-deficient plants, fibrous roots become short and branched, while storage roots become short and have cancers, deformities, and rough skin. New leaves become thick, and both the leaves and the stem near the tip of branches become brittle. For Bdeficient plants, new leaves are lighter in color than old leaves. The leaves can be wrinkled, with the tip and the lateral lobes curled, and the branches have short internodes. Boron toxicity causes necrosis in old leaves, premature senescence, and leaf fall. The leaves are cupped downwards or show curled end. Necrotic spots can be light brown, dark brown, or have dark outlines. The necrotic tissue is brittle and can fall off, leaving leaves punctured.

Cu: Copper deficiency causes chlorosis, wilting, and fall of mature leaves. Chlorosis is interveinal and chlorotic leaves develop spots or necrosis spots that spread throughout the leaf. The surface of young leaves may become silvery. New leaves are usually small, deformed, wrinkled, or thick, and may have holes due to uneven expansion of leaf blade. A reduction in internode length is also common. Copper toxicity prevents the growth of fibrous roots and causes severe wilting and death of the tip of branches. However, Cu toxicity does not cause generalized chlorosis in the leaves or increased red pigmentation. In mature leaves, excess $\mathrm{Cu}$ can cause interveinal chlorosis ranging from light green to white, and symptoms appear only in some leaves of the shoots. Copper toxicity can also induce symptoms of Fe deficiency.

Fe: Iron deficiency causes chlorosis in new leaves, which is initially interveinal (yellow leaf blades and green veins). With the worsening of the symptom, chlorosis evolves to a white color and the veins can lose the green color. Iron deficiency causes young purple leaves to become pink, and severely affected leaf blades to become necrotic. Growth points of the plant may die.

Mn: Manganese deficiency produces small, thin storage roots with streaks in the pulp. The first sign of $\mathrm{Mn}$ deficiency is interveinal chlorosis in middle-aged leaves throughout the plant. Chlorosis can be followed by leaf fall, leaf blade wrinkling, or downward curvature of leaves. Leaf fall is caused by flexion of the petiole and is not preceded by wilting of leaf blades. Severely Mn-deficient leaves become necrotic, with necrosis spreading from the tip or the lateral margins. Manganese toxicity causes necrotic spots on old leaves and severe chlorosis on new leaves due to induced $\mathrm{Fe}$ deficiency. Necrotic spots caused by toxicity are generally more concentrated at the tip and margins of the leaf.

Zn: Zinc deficiency reduces the size of young leaves, and leaves become thicker. Branch internodes become short. General chlorosis of young leaves is common, varying in intensity. An increase in the purple color of the tip of branches can occur in some cultivars. The leaf blades of $\mathrm{Zn}$-deficient plants become narrower and the lateral lobes point more sharply to the leaf tip. Zinc toxicity causes root necrosis. In the leaves, excess $\mathrm{Zn}$ causes dark spots on old leaves and, in more severe cases, promotes red pigmentation of all plant shoots, especially the petioles and the margins and veins of the leaf blade. Excess $\mathrm{Zn}$ also induces severe Fe deficiency in plants.

Al: The main symptom of aluminum toxicity is reduced root development. Under Al toxicity, fibrous roots become short, thick, and there is no development of root hair. As Al toxicity affects the growth of fibrous roots, symptoms of water stress in the shoot may arise in response to the poorly developed root system. Symptoms of $\mathrm{Ca}, \mathrm{Mg}$, and $\mathrm{P}$ deficiency can also occur due to Al toxicity.

\section{Fertilization with macronutrients}

Nitrogen is one of the nutrients most required by sweet potato (Filgueira, 2008; Echer et al., 2009a). This element plays a key role in the growth, yield, and quality of storage roots, mainly because it influences the production and partition of dry matter (DM) in the plant (Oliveira et al., 2005a; Okpara et al., 2009).

Adequate $\mathrm{N}$ supply improves shoot development and increases the leaf area index, favoring the photosynthesis of sweet potato plants and the synthesis of carbohydrates and proteins (Oliveira et al., 2005a; Okpara et al., 2009; Saki et al., 2019). Despite this importance for the sweet potato, this root crop is often cultivated without receiving $\mathrm{N}$ fertilization, or it is cultivated taking advantage of the residual $\mathrm{N}$ from fertilizations carried out in previous crops (Miranda et al., 1995; Filgueira, 2008). This is because excess $\mathrm{N}$ increases gibberellin production, which causes excessive growth of shoots at the expense of the formation of storage roots (Oliveira et al., 2005a; Oliveira et al., 2006a). 
The response of sweet potato to $\mathrm{N}$ fertilization depends on several factors, including rainfall, season, method of fertilizer application, and soil organic matter concentration. In Brazil, there is still no method that accurately indicates soil $\mathrm{N}$ availability due to the complex dynamics of transformations that $\mathrm{N}$ undergoes in the soil. Thus, the recommendations of technical bulletins for $\mathrm{N}$ fertilization in sweet potato, in Brazil, indicate rates between 20 and $60 \mathrm{~kg} \mathrm{ha}^{-1} \mathrm{~N}$ (Lorenzi et al., 1997; Casali, 1999; Silva et al., 2002). However, even in soil with low organic matter concentration $\left(10 \mathrm{~g} \mathrm{dm}^{-3}\right)$ and with application of low $\mathrm{N}$ rates, the sweet potato crop absorbs large amounts of $\mathrm{N}$ ( $350 \mathrm{~kg} \mathrm{ha}^{-1}$ ) (Echer et al., 2009a) (Figure 1). Under growth conditions without $N$ application, sweet potato can absorb between 66 and $89 \mathrm{~kg} \mathrm{ha}^{-1} \mathrm{~N}$ (Hill et al., 1990; Fernandes et al., 2018). This high $\mathrm{N}$ absorption capacity of sweet potato in soils with low fertility demonstrates the association of this crop with a diversity of diazotrophic bacteria, which fix atmospheric N (Terakado-Tonooka et al., 2013).

In Brazil, recent studies in sandy soils and with low organic matter concentration or in areas previously cultivated with pasture have indicated a response of sweet potato to mineral $\mathrm{N}$ fertilization at rates between 102 and $183 \mathrm{~kg} \mathrm{ha}^{-1} \mathrm{~N}$ (Oliveira et al., 2005a; Oliveira et al., 2006a; Foloni et al., 2013; Leonardo et al., 2014; Santos Neto et al., 2017). Under these growth conditions, $\mathrm{N}$ supply in combination with adequate rates of $\mathrm{K}$ led to maximum storage root yield when supplying approximately $112 \mathrm{~kg} \mathrm{ha}^{-1} \mathrm{~N}\left(10 \mathrm{~kg} \mathrm{ha}^{-1}\right.$ at planting and $102 \mathrm{~kg} \mathrm{ha}^{-1}$ at topdressing) (Foloni et al., 2013). However, a recent study in Brazil showed that the $\mathrm{N}$ rate to be applied to sweet potato is not high, and that the cultivation history of the area should be considered for its determination (Fernandes et al., 2018). These authors found that, for sweet potato grown in sandy soil of low fertility and with previous cultivation of nonlegume crops, the optimal rate of $N$ is $76.6 \mathrm{~kg} \mathrm{ha}^{-1}$; however, if the sweet potato is grown after legumes, the amount of mineral $\mathrm{N}$ to be applied decreases to $49.6 \mathrm{~kg} \mathrm{ha}^{-1} \mathrm{~N}$. In other countries, studies with $\mathrm{N}$ fertilization indicate that the ideal $\mathrm{N}$ rate for sweet potato ranges from 0 to $56 \mathrm{~kg} \mathrm{ha}^{-1} \mathrm{~N}$ (Hill et al., 1990; Phillips et al., 2005).

Studies on $\mathrm{N}$ sources for sweet potato are scarce (Ankumah et al., 2003; Alves et al., 2009). In Alabama, USA, sweet potato yield was not affected by the use of urea or ammonium nitrate as $\mathrm{N}$ source (Ankumah et al., 2003). However, in Brazil, sweet potato fertilized with ammonium sulfate showed marketable storage root yield $13 \%$ higher than sweet potato fertilized with urea (Alves et al., 2009), i.e., a small increase in storage root yield. Therefore, more studies are needed to compare the efficiency and cost of $\mathrm{N}$ fertilizer sources for sweet potato.

Regardless of the N source, it is recommended to split the $\mathrm{N}$ fertilizer to increase yield and recovery of the applied N (Alves et al., 2009). Lorenzi et al. (1997) indicate that $\mathrm{N}$ application should be split with half the rate being applied at planting and the rest at topdressing at 30 days after cuttings sprouting. Nevertheless, other authors suggest the application of $1 / 3$ of the $N$ rate at planting and the rest at topdressing between 30 and 60 DAP (Embrapa, 1995; Alves et al., 2009). However, it is noteworthy that topdressing $\mathrm{N}$ fertilization in sweet potato can be dispensed, mainly in areas with previous history of green manure cultivation or in sweet potato fields with vigorous vegetative development at the time of topdressing, as excess $\mathrm{N}$ supply reduces marketable storage root yield and the harvest index of sweet potato (Fernandes et al., 2018; Fernandes et al., 2020). In addition, excess $\mathrm{N}$ associated with greater water availability also reduces tuberization and the development of storage roots in sweet potato.

The response of sweet potato to phosphate fertilization is less than its response to fertilization with $\mathrm{K}$ and $\mathrm{N}$, probably due to the ease of the roots of this crop being associated with arbuscular mycorrhizal fungi native to the soil (Tong et al., 2013; Rós et al., 2015). Under conditions of low soil phosphorus $(P)$ availability, sweet potato plants are highly dependent on symbiosis with arbuscular mycorrhizal fungi for nutrient absorption (Neumann et al., 2009; Tong et al., 2013). Notwithstanding, this association is disadvantaged when high rates of phosphate fertilizers are provided (Filgueira, 2008). A recent study also showed that sweet potato has the ability to maintain a constant and low concentration of $P$ in tissues $\left(<1.0 \mathrm{~g} \mathrm{~kg}^{-1}\right)$ when there is a low supply of $P$ (Minemba et al., 2019). Thus, this crop shows high efficiency in the use of absorbed $P$ (Minemba et al., 2019).

In sweet potato, in addition to improving the yield of storage roots (Oliveira et al., 2005b; Oliveira et al., 2006b; Oliveira et al., 2008), P also interferes with root quality because its supply can increase root starch and total sugar content (Oliveira et al., 2005b; El-Sayed et al., 2011; Abdel-Razzak et al., 2013). However, management of phosphate fertilization in sweet potato must consider the initial soil $P$ availability (soil analysis) since excess $P$ reduces the marketable storage root yield of sweet potato (Oliveira et al., 2005b; Oliveira et al., 2006b; Cruz et al., 2016). This is probably due to the increase in salinity resulting from high concentrations of fertilizers, which reduce storage root growth (Cruz et al., 2016).

When sweet potato is grown in soils with adequate $P$ availability, there is generally no positive response to phosphate fertilization. However, in soils with low initial $P$ availability $\left(P_{\text {Mehlich-1 }}=3.7 \mathrm{mg} \mathrm{dm}^{-3}\right)$, phosphate fertilization significantly increases total storage root yield up to rates close to $259 \mathrm{~kg} \mathrm{ha}^{-1} \mathrm{P}_{2} \mathrm{O}_{5}$ (Oliveira et al., 2005b). Notwithstanding, a recent study with a new sweet potato cultivar (Beauregard) showed that even in soil with medium initial $P$ availability $\left(P_{\text {resin }}=14 \mathrm{mg} \mathrm{dm}^{-3}\right)$, sweet potato responded to rates above $180 \mathrm{~kg} \mathrm{ha}^{-1} \mathrm{P}_{2} \mathrm{O}_{5}$ (Cruz et al., 2016), i.e., above the recommended for this root crop in soils with medium initial P availability (Lorenzi et al., 1997; Casali, 1999; Silva et al., 2002) (Table 3). On the other hand, also in soil with medium initial P availability, Nunes (2019) 
found that phosphate fertilization did not alter the marketable storage root yield of cultivar Uruguaiana, but increased the marketable yield of cultivar Canadense up to the rate of $100 \mathrm{~kg} \mathrm{ha}^{-1} \mathrm{P}_{2} \mathrm{O}_{5}$. This demonstrates that there is a difference between the sweet potato cultivars planted in Brazil with respect to the response to phosphate fertilization.

Table 3 - Recommendation of phosphate and potassium fertilization for sweet potatoes in the states of São Paulo, Minas Gerais, and Espírito Santo. Source: Lorenzi et al. (1997), Casali (1999), and Silva et al. (2002).

\begin{tabular}{lccc}
\hline Availability of $\mathrm{P}$ or $\mathrm{K}$ in the soil & $\begin{array}{c}\text { São Paulo } \\
\text { (Lorenzi et al., 1997) }\end{array}$ & $\begin{array}{c}\text { Minas Gerais } \\
\text { (Casali, 1999) }\end{array}$ & $\begin{array}{c}\text { Espírito Santo } \\
\text { (Silva et al., 2002) }\end{array}$ \\
\cline { 2 - 4 } & \multicolumn{2}{c}{$\mathrm{P}_{2} \mathrm{O}_{5}\left(\mathrm{~kg} \mathrm{ha}^{-1}\right)$} & 90 \\
Low & 100 & 180 & 60 \\
Medium & 80 & 120 & 40 \\
High & 60 & 60 & 100 \\
Low & 120 & $\mathrm{~K}_{2} \mathrm{O}\left(\mathrm{kg} \mathrm{ha}^{-1}\right)^{(1)}$ & 70 \\
Medium & 90 & 90 & 40 \\
High & 60 & 60 & 30 \\
\hline
\end{tabular}

(1) Rates greater than $50 \mathrm{~kg} \mathrm{ha}^{-1}$ should be divided between planting and topdressing.

The literature shows results that prove the differentiated response of sweet potato cultivars to $P$ supply (Li et al., 2020). There are also differences in $\mathrm{P}$ use efficiency (Silva et al., 2013), which indicates the need for adjustment in the management of phosphate fertilization according to the cultivars. However, the current recommendations for phosphate fertilization in sweet potato in Brazil are not yet specific for its cultivars and indicate rates ranging from 40 to $180 \mathrm{~kg} \mathrm{ha}^{-1} \mathrm{P}_{2} \mathrm{O}_{5}$, depending on the initial soil $\mathrm{P}$ availability (Lorenzi et al., 1997; Casali, 1999; Silva et al., 2002) (Table 3).

Potassium $(\mathrm{K})$ is the nutrient most absorbed by sweet potato (Figure 2), being essential for its development (Corrêa et al., 2018). This element is important for sweet potato for its role in enzymatic activation and in carbohydrate formation and conversion into starch, besides acting in the transport of photoassimilates from the leaves to the storage organs (Kumar et al., 2007; Corrêa, 2016). Thus, K acts positively on the mass and flavor of storage roots, improving product quality and market value (Barker \& Pilbeam, 2007; Kumar et al., 2007; Filgueira, 2008; Lebot, 2009; Marschner, 2012; Corrêa, 2016). Nascimento et al. (2019) found that $\mathrm{K}$ increased carotenoid content in orange-fleshed cultivars. This nutrient also interferes with the yield and number of storage roots per plant by considerably increasing the proportion of dry matter allocated to this storage organ (Bourke, 1985).

The positive effects of $\mathrm{K}$ supply on sweet potato yield occur mainly when this root crop is grown in sandy soils and with low levels of exchangeable K. Current recommendations for potassium fertilization in sweet potato in Brazil are based on the available soil $\mathrm{K}$ levels. The recommended rates range from 30 to $120 \mathrm{~kg} \mathrm{ha}^{-1}$ $\mathrm{K}_{2} \mathrm{O}$, depending on the initial soil $\mathrm{K}$ availability and the cultivation region (Lorenzi et al., 1997; Casali, 1999; Silva et al., 2002) (Table 3). However, new sweet potato cultivars have been grown in Brazil, which have shown higher yields. Research with potassium fertilization in cultivars Canadense and Beauregard have indicated $\mathrm{K}$ rates that differ from the official fertilization recommendations (Cecílio Filho et al., 2016; Figueiredo, 2019).

In soils with low $\left(\mathrm{K}=0.7 \mathrm{mmol}_{\mathrm{c}} \mathrm{dm}^{-3}\right)$ and medium initial $\mathrm{K}$ concentration (between 1.4 and $1.5 \mathrm{mmol}_{\mathrm{c}} \mathrm{dm}^{-3}$ ), depending on the form of split application of potassium fertilizer, the marketable storage root yield of cultivar Canadense was maximum with rates between 157 and 207 and between 106 and $128 \mathrm{~kg} \mathrm{ha}^{-1}$ $\mathrm{K}_{2} \mathrm{O}$, respectively. However, in soil with high $\mathrm{K}$ availability $\left(\mathrm{K}=3.0 \mathrm{mmol}_{\mathrm{c}} \mathrm{dm}^{-3}\right)$, potassium fertilization was harmful and reduced the marketable storage root yield of this cultivar by $8.0 \%$ (Figueiredo, 2019). In a Brazilian soil with low $\mathrm{K}$ concentration $\left(\mathrm{K}=0.3 \mathrm{mmol}_{\mathrm{c}} \mathrm{dm}^{-3}\right)$, Cecílio Filho et al. (2016) found maximum marketable storage root yield of cultivar Beauregard with the application of only $85 \mathrm{~kg} \mathrm{ha}^{-1} \mathrm{~K}_{2} \mathrm{O}$. These studies indicate that there may be a need to establish specific potassium fertilization recommendations for each cultivar and soil type.

Excess $\mathrm{K}$, in addition to reducing yield (Figueiredo, 2019), can negatively influence the quality of sweet potato storage roots. In potato (Solanum tuberosum L.), excess $\mathrm{K}$ directly interferes with tuber quality, decreasing firmness and starch content. The increase in $\mathrm{K}$ absorption and accumulation in potato plants decreases the cellular osmotic potential, increasing the internal absorption of water and diluting the starch content in storage organs (Reis Júnior \& Fontes, 1996).

Splitting potassium fertilization, especially in sandy soils, is important to reduce the problems of salinity and leaching (Brito et al., 2006; Rosolem et al., 2006). Moreover, the practice provides $\mathrm{K}$ for sweet potato during the formation of storage roots, i.e., in later stages of the cycle, when the plant's demand for $\mathrm{K}$ is greater (Figure $1 \mathrm{a}, \mathrm{b}$ ). In sandy soils, some authors 
recommend to split potassium fertilization with half the rate at planting and the rest at topdressing together with $\mathrm{N}$ (Corrêa et al., 2018). In K-deficient soils, there is evidence that supplying $\mathrm{K}$ in two applications (topdressing at 40 and 90 DAP) is better than applying the entire rate at planting or with an early application at topdressing, at 40 DAP (Figueiredo, 2019).

Adequate Ca supply is essential to increase the development of sweet potato fibrous roots (O'Sullivan et al., 1997), and Ca deficiency can cause root death (Ichikawa et al., 2019). Magnesium (Mg) is a nutrient that acts in photosynthesis and influences carbohydrate assimilation and translocation in the plant (Gerendás \& Fuhrs, 2013). In crop fertilization, $\mathrm{Ca}$ and Mg are usually supplied by liming, which is the cheapest way to supply these nutrients to plants (Fernandes et al., 2011). The choice of the type of liming will depend on local factors; however, it is preferable to use dolomitic limestone, as in addition to neutralizing aluminum ( $\mathrm{Al})$, it makes $\mathrm{Ca}$ and Mg available to plants (Miranda et al., 1995; Trani \& van Raij, 1997; Fernandes et al., 2011). Experiments with nutrient solution have shown that sweet potato is tolerant to acidity; in the absence of $\mathrm{Al}$, it can grow normally at $\mathrm{pH}_{\text {(water) }}$ less than 4.0 (lla'ava et al., 1996; O'Sullivan et al., 1997). However, Al solubility increases rapidly in the soil at $\mathrm{pH}_{\text {(water) }}$ less than 5.0. Thus, in field conditions, sweet potato has problems with Al toxicity before suffering the direct effects of low pH (O'Sullivan et al., 1997). Acid soils with Al saturation greater than $20 \%$ seriously limit sweet potato yield (Ila'ava et al., 2000). In these soils, sweet potato responds positively to liming (Camargo et al., 1962; Santos Junior et al., 2020 ), with increases in storage root yield up to a $60 \%$ soil base saturation (Figures $3 a, b)$. Therefore, liming is considered a minimum practice of soil fertility management to improve sweet potato yield (Santos Junior et al., 2020).

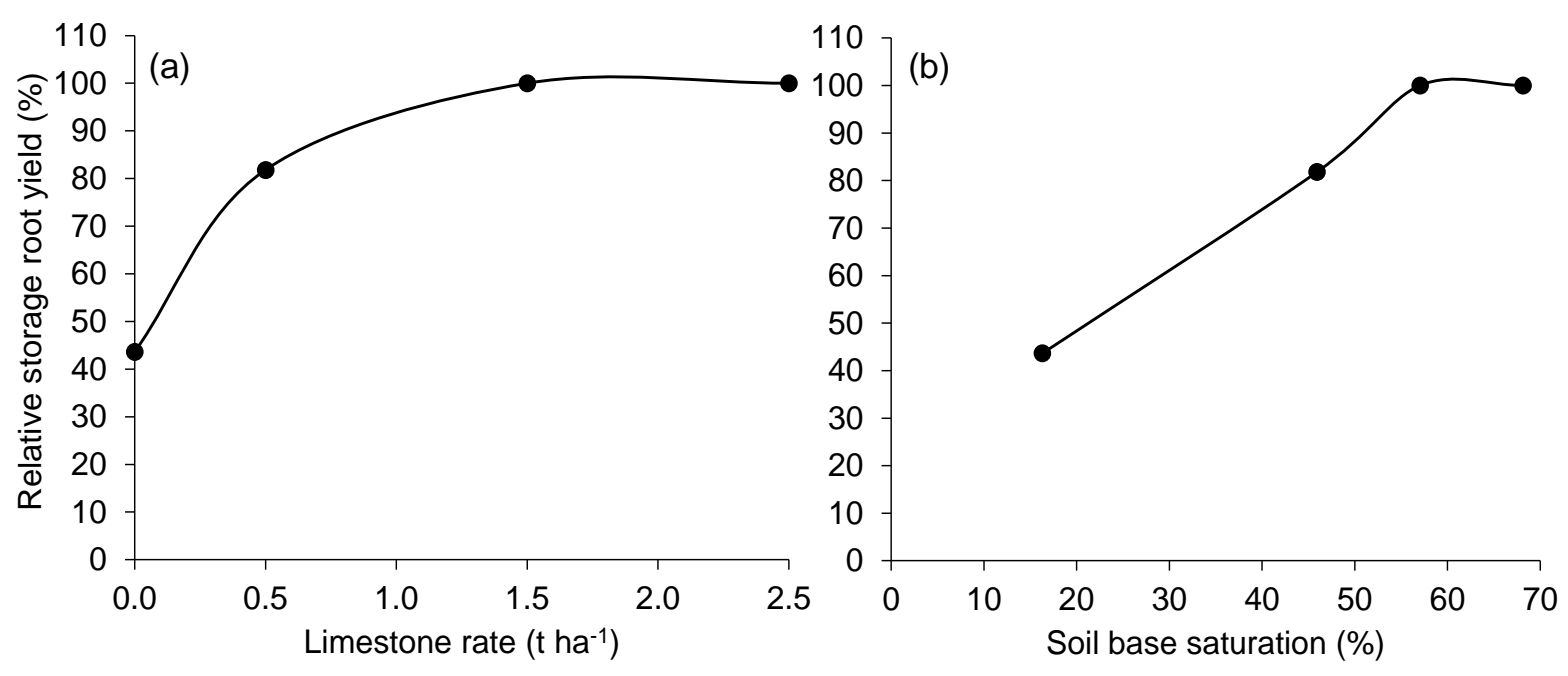

Figure 3. Relative storage root yield of sweet potato in response to liming (a) and relationship of relative storage root yield with soil base saturation (b). Source: (a) values calculated using data from Camargo et al. (1962); (b) values calculated using data from Camargo et al. (1962) and the equation that relates soil pH with soil base saturation $(\mathrm{BS})(\mathrm{pH}=3.66+0.027 \mathrm{BS})$ proposed by Quaggio et al. (1982).

For sweet potato, the recommendation is to apply limestone so as to raise soil base saturation to 60\% (Lorenzi et al., 1997; Casali, 1999) and soil Mg concentrations to minimum values between 4 and $10 \mathrm{mmol}_{\mathrm{c}} \mathrm{dm}^{-3}$, depending on each author recommendation (Lorenzi et al., 1997; Casali, 1999). However, excessive liming can reduce the availability of micronutrients due to the intense increase in soil $\mathrm{pH}$, and high soil $\mathrm{Ca}$ and $\mathrm{Mg}$ concentrations can inhibit $\mathrm{K}$ absorption by plants (Malavolta, 1980; Meurer et al., 2018).

Under Brazilian conditions, sulfate fertilizers have hardly been studied in sweet potato and, therefore, there is no specific recommendation for this crop. On average, the crop absorbs about $0.6 \mathrm{~kg}$ of $S$ per ton of storage root, and $S$ absorption per hectare can reach $39 \mathrm{~kg} \mathrm{ha}^{-1}$ (Figures 1a and 2a). The use of gypsum or
S-containing NPK sources are ways of providing $S$ for sweet potato.

Considering the average absorption of $20 \mathrm{~kg} \mathrm{ha}^{-1}$ $S$ by sweet potato, and the average percentage of recovery of fertilizer $S$ by the crops (40\%) (Cunha et al., 2010), the application of $424 \mathrm{~kg} \mathrm{ha}^{-1}$ simple superphosphate (equivalent to $76 \mathrm{~kg} \mathrm{ha}^{-1} \mathrm{P}_{2} \mathrm{O}_{5}$ ) in the planting furrow, or $212 \mathrm{~kg} \mathrm{ha}^{-1}$ ammonium sulfate (equivalent to $42 \mathrm{~kg} \mathrm{ha}^{-1} \mathrm{~N}$ ) at topdressing, are sufficient to supply the sweet potato demand for S (Table 4). Noteworthy, the sweet potato demand for this nutrient is smaller than for others (Rós et al., 2015). However, in soils with low S concentrations, low organic matter, and which have not received application of S-containing fertilizer, it is recommended to apply about $10 \mathrm{~kg} \mathrm{ha}^{-1} \mathrm{~S}$ (Echer et al., 2015). 
Table 4 - Estimation of $S$ rate to be applied in the form of simple superphosphate and ammonium sulfate in sweet potato, based on total plant S absorption and the use-efficiency of $40 \%$ from S applied via fertilizer.

\begin{tabular}{lc}
\hline Parameters & Values \\
\hline S average absorption by sweet potato $\left(\mathrm{kg} \mathrm{ha}^{-1}\right)^{(1)}$ & 20 \\
Average recovery of S fertilizer (\%) ${ }^{(2)}$ & 40 \\
S rate to supply the sweet potato S demand $\left(\mathrm{kg} \mathrm{ha}^{-1}\right)$ & 51 \\
Amount of simple superphosphate $\left(12 \%\right.$ S) to supply sweet potato S demand $\left(\mathrm{kg} \mathrm{ha}^{-1}\right)^{(3)}$ & 424 \\
Amount of ammonium sulfate $\left(24 \%\right.$ S) to supply sweet potato S demand $\left(\mathrm{kg} \mathrm{ha}^{-1}\right)^{(4)}$ & 212 \\
\hline
\end{tabular}

(1) Average values calculated from the studies of O'Sullivan et al. (1997) and Echer et al. (2009). (2) Cunha et al. (2010).

(3) Equivalent to the supply of $76 \mathrm{~kg} \mathrm{ha}^{-1} \mathrm{P}_{2} \mathrm{O}_{5}$. ${ }^{(4)}$ Equivalent to the supply of $42 \mathrm{~kg} \mathrm{ha}^{-1} \mathrm{~N}$.

\section{Fertilization with micronutrients}

In Brazil, there are still no official recommendations for fertilization with micronutrients in sweet potato crop. However, it is necessary to pay attention to the availability of micronutrients in the soils to be cultivated. If the soil is deficient in micronutrients (Table 5), including these micronutrients in fertilization can improve sweet potato storage root yield.

Table 5 - Range of concentrations for interpretation of micronutrient availability in soils. Source: van Raij et al. (1997).

\begin{tabular}{lccc}
\hline \multirow{2}{*}{ Nutrient } & Low & $\begin{array}{c}\text { Concentration }\left(\mathrm{mg} \mathrm{dm}^{-3}\right) \\
\text { Medium }\end{array}$ & High \\
\hline $\mathrm{B}$ (hot water) & $0-0.2$ & $0.21-0.6$ & $>0.6$ \\
$\mathrm{Cu}$ (DTPA) & $0-0.2$ & $0.3-0.8$ & $>0.8$ \\
$\mathrm{Fe}{ }_{(\text {DTPA })}$ & $0-4.0$ & $5.0-12.0$ & $>12.0$ \\
$\mathrm{Mn}_{\text {(DTPA) }}$ & $0-1.2$ & $1.3-5.0$ & $>5.0$ \\
$\mathrm{Zn}_{(\text {DTPA })}$ & $0-0.5$ & $0.6-1.2$ & $>1.2$ \\
\hline
\end{tabular}

Molybdenum is a micronutrient that is rarely deficient in Brazilian soils, whose critical concentrations or suitable ranges for soil availability have not yet been established (Moraes et al., 2010).

The supply of micronutrients for sweet potato can be via soil or foliar application. The aim is to correct possible deficiencies and properly nourish the plants. However, under Brazilian conditions, few studies have evaluated the response of sweet potato to fertilization with micronutrients (Echer et al., 2009a; Echer \& Creste, 2011).

In soils with low $B$ availability ( $B_{\text {hot water }}=$ $0.13 \mathrm{mg} \mathrm{dm}^{-3}$ ), the supply of $B$, both via soil and foliar application, has increased the marketable storage root yield of sweet potato at rates around $2.0 \mathrm{~kg} \mathrm{ha}^{-1} \mathrm{~B}$ (Echer \& Creste, 2011). The application of this rate of $B$ at topdressing, combined with $\mathrm{K}$ application, has also significantly increased storage root yield (Echer et al., 2009b). Notwithstanding, the response of sweet potato to $B$ application depends on the availability of this micronutrient in the soil.

Research results show that $\mathrm{Zn}$ increases the levels of carotenoids, total sugars, total carbohydrates, crude protein, and the storage root yield of sweet potato (Abd El-Baky et al., 2010). In addition, foliar application of $\mathrm{Zn}$ and $\mathrm{Fe}$, associated with amino acids, has also increased the yield and nutritional quality of sweet potato storage roots (Sun et al., 2019). However, under Brazilian conditions, there is a lack of research on mi- cronutrient fertilization in the sweet potato crop.

In the absence of experimental results on the response of sweet potato to fertilization with micronutrients, by considering the amounts absorbed and the average percentage of micronutrient recovery by crops, it is possible to estimate the amount of micronutrients to be applied for the sweet potato crop, especially in soils poor in micronutrients (Table 6). It is extremely necessary to emphasize that the levels of these micronutrients already available naturally in soils must be considered. Thus, in soils with low micronutrient availability and in the absence of specific fertilization recommendations, at least $8 \mathrm{~kg} \mathrm{ha}^{-1}$ of borax, $0.8 \mathrm{~kg} \mathrm{ha}^{-1}$ of copper sulfate, $15 \mathrm{~kg} \mathrm{ha}^{-1}$ of ferric sulfate, $3.5 \mathrm{~kg} \mathrm{ha}^{-1}$ of manganese chloride, and $1.4 \mathrm{~kg} \mathrm{ha}^{-1}$ of zinc sulfate can be applied to minimize the appearance of deficiency symptoms in plants. If correction of micronutrient deficiencies via foliar spraying is necessary, it must be carried out with the application of $\mathrm{B}, \mathrm{Fe}, \mathrm{Mn}$, and $\mathrm{Zn}$ between 45 and 60 DAP; in turn, Cu applications must occur between 60 and 75 DAP, i.e., close to the periods of the greatest demand of sweet potato for micronutrients (Echer et al., 2009). 
Table 6 - Estimation of micronutrient fertilizer rate to be applied to sweet potato based on the total micronutrient absorbed by plant and in the applied micronutrient use-efficiency of fertilizer.

\begin{tabular}{|c|c|c|c|c|c|}
\hline \multirow{2}{*}{ Parameters } & \multicolumn{5}{|c|}{ Micronutrients } \\
\hline & B & $\mathrm{Cu}$ & $\mathrm{Fe}$ & $\mathrm{Mn}$ & $\mathrm{Zn}$ \\
\hline Amount absorbed by sweet potato $\left(\mathrm{g} \mathrm{ha}^{-1}\right)^{(1)}$ & 254 & 112 & 338 & 539 & 186 \\
\hline Average recovery index (\%) ${ }^{(2)}$ & 30 & 59.8 & 10 & 59.5 & 38 \\
\hline Micronutrient rate to supply $\left(\mathrm{g} \mathrm{ha}^{-1}\right)$ & 847 & 187 & 3380 & 906 & 490 \\
\hline Micronutrient source & Borax & Cu sulfate & Ferric sulfate & Mn Chloride & Zn sulfate \\
\hline Micronutrient concentration in the source (\%) ${ }^{(3)}$ & 11 & 24 & 23 & 26 & 35 \\
\hline Fertilizer rate to supply $\left(\mathrm{kg} \mathrm{ha}^{-1}\right)$ & 8 & 0.8 & 15 & 3.5 & 1.4 \\
\hline
\end{tabular}

(1) Average values calculated from the results of amounts of boron, copper, iron, manganese and zinc absorption verified by O'Sullivan et al. (1997) and Echer et al. (2009). ${ }^{(2)}$ Cunha et al. (2010). ${ }^{(3)}$ van Raij et al. (1997).

\section{Organic fertilization}

Organic fertilization is a way to supply nutrients to sweet potato through organic residues. In these residues, nutrient (macro- and micronutrients) release occurs gradually as the residue degrades in the soil, and the nutrients can be used by sweet potato plants according to their needs throughout the growing cycle (Oliveira et al., 2013; Li et al., 2018).

The response of sweet potato to organic fertilizers depends on soil fertility conditions. When grown in medium to high fertility soils, there is usually either no response to the incorporation of organic residues or excess vegetative development (Santos et al., 2006). However, in low fertility soils, the use of organic fertilizers significantly increases storage root yield (Santos et al., 2006; Oliveira et al., 2010), and the assimilablenutrient availability for plants, such as $\mathrm{N}, \mathrm{P}$, and $\mathrm{S}$ (Oliveira et al., 2010; Silva et al., 2012).

In addition to making nutrients available, organic residues, when incorporated into the soil, improves soil structure, water retention capacity, soil density, and microbial activity, also increasing soil $C$ and $\mathrm{N}$ reserves and crop yield (Brar et al., 2015; Li et al., 2018). In sweet potato, in addition to the improvements mentioned above, the use of organic fertilizer stimulates the lateral growth of storage roots and reduces the formation of deformed roots (Silva et al., 2002; Paulo, 2013).

There are several types of organic residues that can be used as fertilizers. However, in horticulture production in Brazil, cattle manure, goat manure, poultry manure, and castor bean cake are currently the most used by farmers (Souza \& Rezende, 2006; Oliveira et al., 2010; Oliveira et al., 2013; Rós et al., 2014). In sandy soils and soils with low levels of organic matter, it is recommended to use between 10 and $30 \mathrm{t} \mathrm{ha}^{-1}$ composted cattle manure (Casali, 1999; Silva et al., 2002; Santos et al., 2009; Oliveira et al., 2010). Nevertheless, when these manure rates are used, the rate of mineral $\mathrm{N}$ must be reduced by half, or even not included in crop fertilization (Rós et al., 2015). In the case of poultry manure, Santos et al. (2010) observed a linear response in the total yield of sweet potato storage roots up to $12 \mathrm{t} \mathrm{ha}^{-1}$. For Casali (1999), in the conditions of Minas Gerais State, Brazil, organic fertilization with cattle manure can be replaced by the use of $2.5 \mathrm{t} \mathrm{ha}^{-1}$ composted poultry manure.

In addition to improving yield, organic fertilizer improves the quality of harvested products and their nutritional value, reflecting higher levels of vitamins, proteins, dry matter, starch, and balanced levels of minerals (Santos et al., 2006; Oliveira et al., 2013). Oliveira et al. (2013) found that sweet potato fertilized with goat manure had more starch in their storage roots than sweet potato that received organic fertilization with cattle and poultry manure. However, regardless of the source of organic residue used, it is necessary that the organic residue is previously composted.

Organic fertilization with green manure can also provide considerable amounts of nutrients for sweet potato grown in succession (Fernandes et al., 2020). Species of velvet bean (Mucuna aterrima), sunnhemp (Crotalaria juncea), showy crotalaria (Crotalaria spectabilis), jack bean (Canavalia ensiformis), and pigeon pea (Cajanus cajan) have provided good yield results for sweet potato grown in succession (Rós et al., 2015; Fernandes et al., 2018). However, under the conditions of São Paulo State, Brazil, velvet bean seems to be more interesting to supply nutrients for sweet potato grown in succession than showy crotalaria (Fernandes et al., 2020).

Green manure species have a deep root system, which increases the absorption of nutrients mainly in the subsurface layers of the soil (Espíndola et al., 1997) and favors the development of the subsequent crop. A study carried out in Nigeria showed that the yield of sweet potato grown after Mucuna pruriens without mineral fertilizer was similar to the yield of sweet potato grown with mineral NPK fertilizer (Okpara et al., 2004). For sandy soils in São Paulo State, Fernandes et al. (2018) found that green manure with legumes such as velvet bean and showy crotalaria reduced by up to $37.5 \%$ the need for application of mineral $\mathrm{N}$ in the sweet potato crop. This shows that, in addition to the benefits to the soil, green manure is also an interesting option to save mineral fertilizers in sweet potato cultivation areas in Brazil. 


\section{Final considerations}

Sweet potato is a crop that can grow in marginal areas, but this study indicates that balanced liming and fertilization are important practices to increase the storage root yield of this root crop. Potassium (K) and nitrogen $(\mathrm{N})$ are the nutrients most absorbed and removed by sweet potato, but excess $\mathrm{N}$ supply can excessively increase vegetative growth and reduce storage root yield. The low response of sweet potato to mineral $\mathrm{N}$ is due to the ability of this crop to associate with $\mathrm{N}$-fixing microorganisms. In most cases, the amounts of $\mathrm{N}$ absorbed by plants (even in soil with low organic matter) are greater than the amounts of $\mathrm{N}$ applied via fertilizer. For this reason, soil management techniques in sweet potato that favor the multiplication of $\mathrm{N}$-fixing microorganisms should be encouraged. Potassium (K) is an important nutrient for sweet potato, but attention must be paid to its soil availability. In soils with $\mathrm{K}$ concentrations equal to or above $3.0 \mathrm{mmol}_{\mathrm{c}} \mathrm{dm}^{-3}$, supplying this nutrient reduces the marketable storage root yield of sweet potato. The most recent research indicates that it is necessary to update fertilization recommendations with $\mathrm{P}$ and $\mathrm{K}$, as there seems to be a different response from the cultivars. The use of $\mathrm{S}$ containing fertilizers should be encouraged in sweet potato cultivation areas to prevent possible deficiencies of $S$ in this crop. Boron (B) supply has been shown to be important for increasing sweet potato yield in sandy and in B-deficient soils but maintaining adequate levels of other micronutrients in soils cultivated with sweet potato is also essential for achieving high storage root yield. Organic fertilization, whether with animal manure or green manure, should be stimulated, as it is extremely efficient for increasing sweet potato yield and improving root shape. Furthermore, organic fertilizers can replace, even partially, mineral fertilizers.

\section{References}

Abd El-Baky MMH, Ahmed AA, El-Nemr MA, Zaki MF (2010) Effect of potassium fertilizer and foliar zinc application on yield and quality of sweet potato. Research Journal of Agricultural and Biological Science 6(4):386394.

Abdel-Razzak HS, Moussa AG, El-Fattah A, El-Morabet GA (2013) Response of sweet potato to integrated effect of chemical and natural phosphorus fertilizer and their levels in combination with mycorrhizal inoculation. Journal of Biological Sciences 13(3):112-122.

Alves AU, Oliveira AP, Alves EU, Oliveira A NP, Cardoso EA, Matos BF (2009) Manejo da adubação nitrogenada para batata-doce: fontes e parcelamento de aplicação. Ciência Agrotécnica 33(6):1554-1559.

Ankumah RO, Khan V, Mwamba K, Kpomblekou-A K (2003) The influence of source and timing of nitrogen fertilizers on yield and nitrogen use efficiency of four sweet potato cultivars. Agriculture, Ecosystems and Environment 100:201-207.
Barker AV, Pilbeam DJ (2007) Handbook of plant nutrition. CRC Press. 773 p.

Bourke RM (1985) Influence of nitrogen and potassium fertilizer on growth of sweet potato (Ipomoea batatas) in Papua New Guinea. Field Crops Research 12:363-375.

Brar BS, Singh J, Singh G Kaur G (2015) Effects of long term application of inorganic and organic fertilizers on soil organic carbon and physical properties in maizewheat rotation. Agronomy 5:220-238.

Brito $\mathrm{CH}$, Oliveira AP, Alves AU, Dorneles CSM, Santos JF, Nóbrega JPR (2006) Produtividade da batata-doce em função de doses de $\mathrm{K}_{2} \mathrm{O}$ em solo arenoso. Horticultura Brasileira 24(3):320-323.

Camargo AP, Freire ES, Venturini WR (1962) Efeito da calagem e de diversas adubações na batata-doce e no cará, em solos de baixa fertilidade, derivados do arenito Botucatu. Bragantia 21:143-161.

Casali VW (1999) Batata-doce. In: Ribeiro AC, Guimarães PTG, Alvarez VH (eds.) Recomendações para o uso de corretivos e fertilizantes em Minas Gerais-5a Apoximação. CFSEMG: Viçosa. 180p.

Cecílio Filho AB, Nascimento S, Silva AS, Vargas PF (2016) Agronomic performance of sweet potato with different potassium fertilization rates. Horticultura Brasileira 34(4):588-592.

Corrêa CV (2016) Produção e qualidade de batata-doce em função das doses e parcelamento da adubação potássica. Unesp-Botucatu (Dissertação de mestrado em Agronomia/Horticultura).

Corrêa CV, Gouveia AMDS, Lanna NDBL, Tavares AEB, Mendonça VZ, Campos FG, Evangelista RM (2018) The split application of potassium influence the production, nutrients extraction, and quality of sweet potatoes. Journal of Plant Nutrition 41(16):2048-2056.

Cruz SMC, Cecílio Filho AB, Nascimento AS, Vargas PF (2016) Mineral nutrition and yield of sweet potato according to phosphorus doses. Comunicata Scientiae 7(2):183-191.

Cunha JF, Casarin V, Prochnow Li (2010) Balanço de nutrientes na agricultura brasileira. In: Prochnow LI, Casarin V, Stipp SR (eds). Boas práticas para uso eficiente de fertilizantes: nutrientes. Piracicaba: IPNI. p.311-352.

Echer F, Creste J (2011) Adubação com boro em batata-doce: efeito das fontes, doses e modos de aplicação. Semina 32:1831-1836.

Echer FR, Creste JE (2015) Recomendação de adubação e diagnose foliar. In: Echer FR, Creste JE, La Torre EJR (eds.) Nutrição e adubação da batata-doce. UNOESTE: Presidente Prudente. p.57-66. 
Echer FR, Creste JE, la Torre EJR (2015) Nutrição e adubação da batata-doce. Presidente Prudente/ Universidade do Oeste Paulista. 94p.

Echer FR, Dominato JC, Creste JE (2009a) Absorção de nutrientes e distribuição da massa fresca e seca entre órgãos de batata-doce. Revista Horticultura Brasileira 27:(2):176-182.

Echer FR, Dominato JC, Creste JE, Santos DH (2009b) Fertilização de cobertura com boro e potássio na nutrição e produtividade da batata-doce. Horticultura Brasileira 27:(2):167-171.

El-Sayed HEA, El-Dean AS, Ezzat S, El-Morsy AHA (2011) Responses of productivity and quality of sweet potato to phosphorus fertilizer rates and application methods of the humidic acid. Research Journal Agricultural Science and Soil Science 1(9):383-393.

Embrapa (1995) - Empresa Brasileira de Pesquisa Agropecuária. Cultivo da batata-doce (Ipomoea batatas L. Lam). Brasília: Embrapa. 32 p.

Espíndola JAA, Guerra JGM, Almeida DL (1997) Adubação verde: Estratégia para uma agricultura sustentável. Seropédica: Embrapa-Agrobiologia. 20p. (Embrapa-CNPAB. Documentos, 42).

Faquin $V$ (2002) Diagnose do estado nutricional das plantas. Lavras: UFLA/FAEPE. $77 \mathrm{p}$.

Fernandes AM, Assunção NS, Ribeiro NP, Gazola B, Silva RM (2020) Nutrient uptake and removal by sweet potato fertilized with green manure and nitrogen on sandy soil. Revista Brasileira de Ciência do Solo 44:1-25.

Fernandes AM, Campos LG, Senna MS, da Silva CL, Assunção NS (2018) Yield and nitrogen use efficiency of sweet potato in response to cover crop and nitrogen management. Agronomy Journal 110(5):2004-2015.

Fernandes AM, Soratto RP, Silva BL (2011) Extração e exportação de nutrientes em cultivares de batata: I - Macronutrientes. Revista Brasileira de Ciência do Solo 35(6):2039-2056 .

Figueiredo RT (2019) Manejo da adubação potássica na cultura da batata-doce. Unesp-Botucatu (Dissertação de mestrado em Agronomia/Horticultura).

Filgueira FAR (2008) Novo Manual de Olericultura: agrotecnologia moderna na produção e comercialização de hortaliças. Viçosa: UFV. 421p.

Foloni JSS, Corte AJ, Corte JRN, Echer FR, Tiritan CS (2013) Adubação de cobertura na batata-doce com doses combinadas de nitrogênio e potássio. Semina: Ciências Agrárias 34(1):117-126.
Gerendás J, Fuhrs H (2013) The significance of magnesium for crop quality. Plant and Soil 368(1-2): 101-128.

Hill WA, Dodo H, Hahn SK, Mulongoy K, Adeyeye SO (1990) Sweet potato root and biomass production with and without nitrogen fertilization. Agronomy Journal 82:1120-1122.

Ichikawa ETM, Fernandes AM, Mota LHSO (2019) Enraizamento de mudas de batata-doce submetidas a nutrição suplementar com cálcio e fósforo no substrato. Revista Brasileira de Engenharia Agrícola e Ambiental 23(11):860-868.

Ila'ava VP, Blamey FPC, Asher CJ (1996) Sensitivity of sweet potato lines to $\mathrm{Ca}$ and $\mathrm{Al}$ stress in solution culture. In: Craswell ET, Asher CJ, O'Sullivan JN (eds.). ACIAR Proceedings No. 65: Mineral nutrient disorders of root crops in the Pacific. p.53-57.

lla'ava VP, Blamey P, Asher CJ (2000) Effects of lime and gypsum on growth of sweet potato in two strongly acid soils. Australian Journal of Agricultural Research 51(8):1031-1037.

Kumar P, Pandey SK, Singh BP, Singh SV, Kumar D (2007) Influence of source and time of potassium application on potato growth, yield, economics and crisp quality. Potato Research 50(1):1-13.

Lebot V (2009) Tropical root and tuber crops: cassava, sweet potato, yam, aroids. Cambridge: $\mathrm{CABI}, 413 p$.

Leonardo FAP, Oliveira AP, Pereira WE, Silva POR, Barros JRA (2014) Rendimento da batata-doce adubada com nitrogênio e esterco bovino. Revista Caatinga 27(2):18-23.

Li C, Wang J, Zhang YC (2020) Root growth and phosphorus efficiency among sweet potato genotypes under low phosphorus. Journal of Plant Nutrition 43(9):1320-1330.

Li XP, Liu CL, Zhao H, Gao F, Ji GN, Hu F, Li HX (2018) Consistent improvements in soil biochemical properties and crop yields by organic fertilization for above-ground (rapeseed) and below-ground (sweet potato) crops. The Journal of Agricultural Science 156(10):1186-1195.

Lorenzi JO, Monteiro PA, Miranda Filho HS, Raij B van (1997) Raízes e tubérculos. In: Raij B. van, Cantarella $\mathrm{H}$, Quaggio JA, Furlani AMC (eds.). Recomendações de adubação e calagem para o Estado de São Paulo. Campinas: Instituto Agronômico de Campinas (Boletim Técnico, 100), p.221-229.

Malavolta E (1980) A avaliação do estado nutricional. In: Malavolta, E. Elementos de nutrição mineral de plantas. São Paulo: Agronômica Ceres:219-251. 
Marschner P (2012) Mineral Nutrition of Higher Plants. Academic Press: London. p. 178-189.

Meurer EJ, Tiecher T, Mattielo L (2018) Potássio. In: Fernandes MS, Souza SR, Santos LA (eds). Nutrição Mineral de Plantas Viçosa: Sociedade Brasileira de Ciência do Solo. p. 429-464.

Minemba D, Gleeson DB, Veneklaas E, Ryan MH (2019) Variation in morphological and physiological root traits and organic acid exudation of three sweet potato (Ipomoea batatas) cultivars under seven phosphorus levels. Scientia Horticulturae (Amsterdam) 256:108572.

Miranda JEC, França FH, Carrijo AO, Souza AF, Pereira W, Lopes CA, Silva JBC (1995) A cultura da batata-doce. Brasília: Embrapa-CNPH. Coleção Plantar $94 \mathrm{p}$.

Moraes MF, Abreu Junior CH, Lavres Junior J (2010) Micronutrientes. In: Prochnow LI, Casarin V, Stipp SR (eds). Boas práticas para uso eficiente de fertilizantes: nutrientes. Piracicaba: IPNI. p.311-352.

Nascimento SMC, Cecílio Filho AB, Silva ASN, Vargas PF (2019) Rendimento de caroteno em batata-doce após aplicação do fertilizante de potássio e fósforo. Revista Caatinga 32(3):851-857.

Neumann E, Schmid B, Römheld V, George E (2009) Extraradical development and contribution to plant performance of an arbuscular mycorrhizal symbiosis exposed to complete or partial rootzone drying. Mycorrhiza 20(1):13-23.

Nunes JGS (2019) Efeitos das épocas de plantio e das doses de fósforo sobre a produtividade e qualidade de cultivares de batata-doce. Unesp-Botucatu (Dissertação de mestrado em Agronomia/Energia na agricultura).

O'Sullivan JN, Asher CJ, Blamey FPC (1997) Nutrient disorders of sweet potato. Australian Centre for International Agricultural Research: Canberra. $136 \mathrm{p}$.

Okpara DA, Njoku JC, Asiegbu JEV (2004) Responses of two sweet potato varieties to four green manure sources and inorganic fertilizer in a humid tropical ultisol. Biological Agriculture and Horticulture 22(1):81-90.

Okpara DA, Okon OE, Ekeleme F (2009) Optimizing nitrogen fertilization for production of white and orange-fleshed sweet potato in Southeast Nigeria. Journal of Plant Nutrition 32(5):878-891.

Oliveira AP, Moura MF, Nogueira DH, Chagas NG, Braz MSS, Oliveira MRT, Barbosa JA (2006a) Produção de raízes de batata-doce em função do uso de doses de $\mathrm{N}$ aplicadas no solo e via foliar. Horticultura Brasileira 24(3):279-282.
Oliveira AP, Oliveira MRT, Barbosa JA, Silva GG, Nogueira DH, Moura MF, Braz MSS (2005a) Rendimento e qualidade de raízes de batata-doce adubada com níveis de ureia. Horticultura Brasileira 23(4):925928.

Oliveira AP, Santos JF, Cavalcante LF, Pereira WE, Santos MCCA, Oliveira ANP, Silva NV (2010) Yield of sweet potato fertilized with cattle manure and biofertilizer. Horticultura Brasileira 28: 277-281.

Oliveira AP, Silva JEL, Pereira WE, Barbosa LJN (2005b) Produção da batata-doce em função de doses de $\mathrm{P}_{2} \mathrm{O}_{5}$ em dois sistemas de plantio. Horticultura Brasileira 23(3):768-772.

Oliveira AP, Silva JEL, Pereira WE, Barbosa LJN (2008) Produção de batata-doce e teor de amido nas raízes em função de doses de $\mathrm{P}_{2} \mathrm{O}_{5}$. Acta Scientiarum Agronomy 27(4):747-751.

Oliveira AP, Silva JEL, Pereira WE, Barbosa LJN, Oliveira ANP (2006b) Características produtivas da batata-doce em função de doses de $\mathrm{P}_{2} \mathrm{O}_{5}$, de espaçamentos e de sistemas de plantio. Ciência e Agrotecnologia 30(4):611-617.

Oliveira AP, Gondim PC, Silva, Ovídio PRS, Oliveira ANP, Gondim SC, Silva JA (2013) Produção e teor de amido da batata-doce em cultivo sob adubação com matéria orgânica. Revista Brasileira de Engenharia Agrícola e Ambiental 17(8):830-834.

Paulo EM (2013) Nutrição e adubação. In: Montes SMNM (ed) Cultura da batata-doce: do plantio a comercialização. Campinas: IAC, p.25-32.

Phillips SB, Warren JG, Mullins GL (2005) Nitrogen rate and application timing affect 'Beauregard' sweetpotato yield and quality. HortScience 40:214-217.

Quaggio JA, Dechen AR, van Raij B (1982) Efeitos da aplicação de calcário e gesso sobre a produção de amendoim e lixiviação de bases no solo. Revista Brasileira de Ciência do Solo 6:182-194.

Reis Júnior RA, Fontes PCR (1996) Qualidade de tubérculos de batata em função de doses da adubação potássica. Horticultura Brasileira 4(3):170-174.

Rós $A B$, Fernandes AM, Montes SMN, Fischer $\mathrm{IH}$, Leonel M, Franco CML (2015) Batata-doce (Ipomoea batatas). In: Leonel M, Fernandes AM, Franco CML (coord). Culturas amiláceas batata-doce, inhame, mandioca e mandioquinha-salsa. Botucatu: CERAT/UNESP. p.15-120.

Rós AB, Narita N, Hirata ACS (2014) Produtividade de batata-doce e propriedades físicas e químicas de solo em função de adubação orgânica e mineral. Semina: Ciências Agrárias 35(1):205-214. 
Rosolem CA, Garcia RA, Simoneti JS, Calonego JC (2006) Lixiviação de potássio no solo de acordo com suas doses aplicadas sobre palha de milheto. Revista Braseira de Ciência do Solo 30(5):813-819.

Saki T, Yomi M, Rajashekhar Rao BK (2019) Critical nitrogen content and nitrogen nutrition index for sweetpotato crop. Journal of Plant Nutrition 42(15):1750-1759.

Santos JF, Brito CH, Santos MCCA (2010) Avaliação da produção de batata-doce em função de níveis de adubação orgânica. Acta Scientiarum Agronomy 32(4):663-666.

Santos JF, Oliveira AP, Alves AU, Dornelas CSM, Brito $\mathrm{CH}$, Nóbrega JPR (2006) Produção de batata-doce adubada com esterco bovino em solo com baixo teor de matéria orgânica. Horticultura Brasileira 24(1):103-106.

Santos JF, Sousa MR, Santos MCCA (2009) Resposta da batata-doce (Ipomoea batatas) à adubação orgânica. Revista Tecnologia \& Ciência Agropecuária 3(1):13-16.

Santos Junior RB, Souza TAF, Santos D, Ferreira PV, Cavalcante JT (2020) Desempenho agronômico de genótipos de batata-doce em função do manejo da calagem e adubação mineral. Revista Brasileira de Ciências Agrárias (Agrária) 15(1):1-5.

Santos Neto AR, Silva TO, Blank AF, Silva JO, Araújo Filho RN (2017) Produtividade de clones de batatadoce em função de doses de nitrogênio. Horticultura Brasileira 35(3):445-452.

Silva JA, Oliveira AP, Alves GS, Cavalcante LF, Oliveira ANP, Araújo MAM (2012) Rendimento do inhame adubado com esterco bovino e biofertilizante no solo e na folha. Revista Brasileira de Engenharia Agrícola e Ambiental 16:253-257.

Silva JBC, Lopes CA, Magalhães JS (2002) Cultura da batata-doce. In: Cereda, M.P. (coord.). Agricultura: tuberosas amiláceas Latino Americanas. São Paulo: Fundação Cargill. p.448-504.
Silva LL, Silveira MA, Fidelis RR, Tavares RC, Momenté VG, Nascimento IR (2013) Seleção de genótipos de batata-doce quanto à eficiência ao uso do fósforo em solos da região de cerrado. Journal of Biotechnology and Biodiversity 4(4):356-364.

Souza GA, Pinho PJ, Bastos ARR, Coelho LC, Botrel ÉP, Carvalho JG (2015) Omissão simples de B e múltiplas com $\mathrm{Ca}, \mathrm{Fe}, \mathrm{Mn}$ e $\mathrm{Zn}$ em mamoneira (Ricinus communis). Revista Agrarian 8(29):287-295.

Souza JL, Resende P (2006) Manual de Horticultura Orgânica. Aprenda fácil, Viçosa: UFV. 843p.

Sun Y, Wenhai M, Lianghuan W (2019) Effects of foliar $\mathrm{Fe}$ and $\mathrm{Zn}$ fertilizers on storage root $\mathrm{Fe}, \mathrm{Zn}$, and betacarotene content of sweet potato (Ipomoea batatas L.). Journal of Plant Nutrition 42(1):16-26.

Terakado-Tonooka J, Fujihara S, Ohwaki Y (2013) Possible contribution of Bradyrhizobium on nitrogen fixation in sweet potatoes. Plant Soil 367:639-650.

Tong Y, Neumann GE, Ngwene B, Krumbein A, Baldermann S, Schreiner M, George E (2013) Effects of single and mixed inoculation with two arbuscular mycorrhizal fungi in two different levels of phosphorus supply on $\beta$-carotene concentrations in sweet potato (Ipomoea batatas L.) tubers. Plant and Soil 372(1-2):361-374.

Trani PE, Raij B (1997) Hortaliças. In: Raij B, Cantarella $\mathrm{H}$, Quaggio JA, Furlani AMC (eds). Recomendações de adubação e calagem para o estado de São Paulo. Campinas: IAC. p. 157-185. (Boletim técnico 100).

van Raij B, Cantarela H, Quaggio JA, Furlani AMC (1997) Recomendações de adubação e calagem para o Estado de São Paulo. 2.ed. Campinas, Instituto Agronômico de Campinas, Fundação IAC, 285p. 